\title{
Diets of Wild Horses, Cattle, and Mule Deer in the Piceance Basin, Colorado
}

\section{RICHARD E. HUBBARD AND RICHARD M. HANSEN}

Highlight: Diets of free-roaming wild horses, domestic cattle, and mule deer were estimated for three altitudinally different vegetation zones in the Piceance Basin, northwestern Colorado. Wild horses and cattle ate mostly grasses and sedges in each of the vegetation zones. Mule deer diets consisted primarily of browse. Wild horse and cattle diets compared within a vegetation zone were more similar to each other than diets of a single herbivore compared between vegetation zones. The percentages of the diets of wild horses and cattle that were identical ranged from $59 \%$ to $75 \%$ in the three vegetation zones. Diet overlap of wild horses or cattle with mule deer was always less than $11 \%$. The diversities of plants on the diets were lower for mule deer than for cattle or wild horses.

The Piceance Basin is an area where information on the interactive feeding relations of mule deer (Odocoileus hemionus), cattle (Bos taurus), and wild horses (Equus caballus) is particu-

The authors are graduate student and professor, Range Science Department, Colorado State University, Fort Collins 80523 . The present address of R. E. Hubbard is Bureau of Land Management, Kemmerer, Wyoming 83101

This study has been supported by funds from Colorado State University Experiment Station Project 1069 and the Bureau of Land Management. We are sincerely grateful to $T$. M. Foppe for laboratory assistance and to G. C. Burrell for his expertise in the microhistological analyses of these samples, and to S. Steinert, J. Sazama, and R. Clark for assisting with the sample collections.

Manuscript received November 4, 1975. larly necessary. ${ }^{1}$ Long-time residents of the area agree that wild horses are increasing and mule deer are decreasing in the study area. Since 1971, the wild horses have been increasing on many other National Resource Lands (Cook, 1975). There is growing concern about the effects which wild horses and cattle may have had on the declining deer populations. Much of the area seems destined for oil shale development and subsequent reclamation. If an objective of revegetation is to provide forage for the large herbivores of the area, or if it is desirable to revegetate with less palatable plants to insure the success of the revegetation (Cook et al., 1974), the most important foods of the large herbivores of the area must be determined.

Allocating forage for big game and livestock has usually been done by intuition and at the expense of one of the species. Cook (1954) determined stocking conversion ratios for sheep and cattle. Davis (1952) and the Committee of the Soil Conservation Workshops (1957) estimated ratios for cattle and deer on Texas rangelands. To estimate combined populations of wildlife, livestock, and wild horses that can be supported on a given range, it is necessary to know the diets of the animals, and the kinds, amounts, and distribution of forage plants. Studies on

'Scientific names not included are in the Tables. 
deer and livestock diets and relationships show large variation between year of study, location, and sampling technique (Schwan, 1945; Julander, 1955; Mackie, 1970; McKean and Bartmann, 1971; Constan, 1973; Kufeld et al., 1973; Hansen and Reid, 1975).

This study determined the consumption ratios of preferred plant species by three herbivores in three different vegetation zones. Mule deer, cattle, and wild horses had a free choice of range plants on the same areas. Results of the study may be useful for evaluating stocking rate manipulations between wild horses, cattle, or mule deer.

\section{Study Areas}

The study areas were about $60 \mathrm{~km}$ southwest of Meeker in the western portion of Piceance Basin, Rio Blanco County, northwestern Colorado (Fig. 1). Five study areas were used on each of three altitudinal vegetation zones. The mixed mountain shrub areas were along the top of Cathedral Bluffs at 2,590 to 2,631 $\mathrm{m}$ in elevation. The pinyon-juniper woodland study areas were about $15 \mathrm{~km}$ east at 2,000 to 2,190 m elevation (Fig. 1). The annual precipitation rate varied from an excess of $60 \mathrm{~cm}$ in the mountain shrub zone to about $38 \mathrm{~cm}$ in the pinyon-juniper zone (Cook, 1974).

$$
\begin{aligned}
& \text { LEGEND } \\
& 1 \text { = MOUNTAIN SHRUB VEGE TATION } \\
& 2 \text { = ECOTONE VEGETATION } \\
& 3 \text { = PINYON - JUNIPER VEGETATION }
\end{aligned}
$$
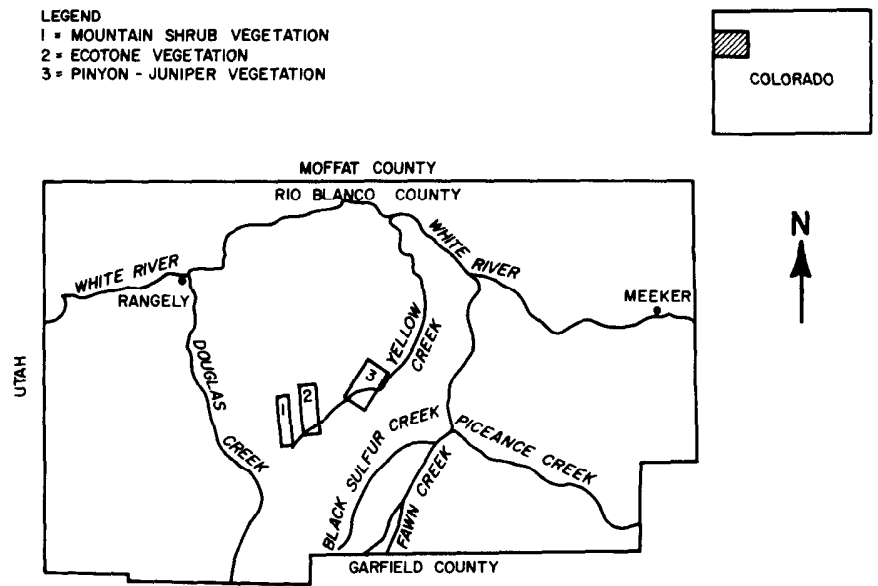

Fig. 1. Map showing generalized locations of the vegetation zones sampled within the Piceance Basin, which includes lands in the drainages of Yellow Creek and Piceance Creek, Rio Blanco County, Colorado.

Many species of plants occur in all three zones, but some are characteristically most abundant at either the highest or lowest elevational zones (Baker, 1970; Cook, 1974). A few pockets of Douglasfir (Pseudotsuga menziesii), quaking aspen (Populus tremuloides), and chokecherry (Prunus sp.) occur only in the mountain shrub zone. Utah serviceberry, Gambel oak, snowberry, and sedges are most bundant in the mountain shrub zone, least abundant in the pinyon-juniper, and intermediately abundant in the ecotone zone. Pinyon pine, junipers (Juniperus osteosperma and J. scopulorum), and basin big sagebrush are dominant plants at the lowest zone. Indian ricegrass and bluegrasses are more abundant as elevations decrease.

Resident wild horses lived in each vegetation zone throughout the year and appear to be least abundant in the pinyon-juniper zone (W. Lawhorn, BLM, personal communication, 1974). Cattle are present on all the areas from early July to late September each year (Lawhorn, pers. commun.). Resident deer occur in each zone from mid April to early November. Migratory mule deer concentrate in the pinyonjuniper zone from early November until mid April (Baker, 1970).

\section{Methods}

The botanical compositions of diets were determined by microscopic analyses of samples of fecal material. Fecal samples for the three herbivores were collected in June, 1974, from each of the 15 areas. Sample areas varied from 10 to 20 hectares in size. Collectors randomly subsampled undecomposed fecal droppings as they came upon them with no regard to season. A subsample of feces weighing about two grams was taken from each wild horse, cow, or deer defecation. A minimum of 50 of each herbivore's defecations were subsampled at each of the 15 areas and compositcd into a single sample for each herbivore diet at each area. The majority of the fecal material probably represented the previous 2 years of feeding activity by mule deer, cattle, and wild horses while they used an area.

An experienced technician identified and quantified the plant fragments in feces as described by Sparks and Malechek (1968), Flinders and Hansen (1972), and Hansen et al., (1973). Fields on each microscope slide were viewed under a binocular microscope at $100 \times$ for identifiable plant fragments. Twenty slides were made per fecal sample and 20 fields were examined per slide, for a total of 400 fields per fecal sample.

The relative percentage of recognized plant fragments in each fecal sample was estimated by procedures described by Sparks and Malechek (1968) and Flinders and Hansen (1972). Previous studies indicate the estimated percentage of identified plant fragments is a good approximation of the percentage relative dry weight of each food category in the diet (Dearden et al., 1975; Hansen et al., 173; Todd and Hansen, 1973).

Multivariate analyses of variance (Morrison, 1967; Dixon, 1972) were used to compare the 45 diets. Major foods used as variables included sedges, wheatgrasses, needleandthread, prairie Junegrass, Indian ricegrass, Utah serviceberry, common winterfat, bromes, bluegrasses, pinyon, junipers, barberry, bladderpod, and big sagebrush. These categories of foods comprised at least $80 \%$ of the total percentage composition of each of the 45 diets.

Similarity of diets was calculated using Kulcyznski's formula (Oosting, 1956). The similarity index represented the percentage of the forage shared by two herbivores that was identical. Plant categories were ranked in the order of their percentage of the diet, and a correlation coefficient was calculated betwen the orders of abundance of foods in two diets (Siegel, 1956).

The "diversity" of foods in diets was calculated by Shannon's (1948) formula. This diversity index when calculated from percentages in diets was named "trophic diversity" by Hurtubia (1973). Analysis of variance (Snedecor and Cochran, 1973) and the NewmanKeuls multiple range test (Miller, 1966) were used to test for differences in trophic diversities among vegetation types and among species of herbivores.

Unless otherwise noted, means and standard deviations are shown in text and tables. Statistical differences were accepted at the 5\% level of significance. Common and scientific names of plants follow those recommended by Beetle (1970).

\section{Results}

Mean diets averaged over the three vegetation zones were significantly different for the three herbivores, and mean diets averaged over the three herbivores were significantly different for the three vegetation zones (Table 1). At least two herbivores made diet adjustments in the three vegetation zones in a different manner.

Wild horse and cattle diets were significantly more similar than either was to diets of mule deer. Wild horse and cattle diets within a vegetation zone (Table 2) were significantly more similar to each other than were the diets of a single herbivore compared between vegetation zones (Table 3).

Analysis of variance of trophic diversities indicated that sources of variation for herbivore species and vegetation zones were highly significant $(\alpha \times .01)$. The trophic diversity indexes for the three vegetation zones for the wild horses and deer were not different and for cattle, the only significant difference was between pinyon-juniper and mountain shrub zones (Table 4). Mule deer had lower trophic diversities in the diets than either wild horses or cattle, except in the mountain shrub zone where deer and cattle had similar trophic diversities (Table 4). 
Table 1. Foods (mean $\% \pm$ standard deviation) making up $2 \%$ or more of an average diet of wild horses, cattle, and mule deer in three vegetation zones, Piceance Basin, Colo., 1974.

\begin{tabular}{|c|c|c|c|c|c|c|c|c|c|}
\hline \multirow{3}{*}{ Plant name } & \multicolumn{3}{|c|}{ Wild horses } & \multicolumn{3}{|c|}{ Cattle } & \multicolumn{3}{|c|}{ Mule deer } \\
\hline & $\begin{array}{l}\text { Mountain } \\
\text { shrub }\end{array}$ & Ecotone & $\begin{array}{l}\text { Pinyon- } \\
\text { juniper }\end{array}$ & $\begin{array}{l}\text { Mountain } \\
\text { shrub }\end{array}$ & Ecotone & $\begin{array}{l}\text { Pinyon- } \\
\text { juniper }\end{array}$ & $\begin{array}{c}\text { Mountain } \\
\text { shrub }\end{array}$ & Ecotone & $\begin{array}{l}\text { Pinyon- } \\
\text { juniper }\end{array}$ \\
\hline & & & & & & & & & \\
\hline \multicolumn{10}{|l|}{ Grasses and grasslikes } \\
\hline Sedge (Carex spp.) & $46 \pm 23$ & $20 \pm 11$ & $6 \pm 7$ & $60 \pm 8$ & $21 \pm 8$ & $13 \pm 9$ & $1 \pm 2$ & $<1$ & $<1$ \\
\hline Needleandthread (Stipa comata) & $8 \pm 6$ & $24 \pm 13$ & $32 \pm 16$ & $6 \pm 4$ & $22 \pm 5$ & $11 \pm 6$ & $<1$ & $1 \pm 2$ & $<1$ \\
\hline Wheatgrasses (Agropyron spp.) & $10 \pm 4$ & $18 \pm 13$ & $10 \pm 7$ & $9 \pm 7$ & $31 \pm 14$ & $9 \pm 1$ & $<1$ & $<1$ & $<1$ \\
\hline Prairie Junegrass (Koeleria cristata) & $12 \pm 7$ & $10 \pm 3$ & $7 \pm 4$ & $9 \pm 3$ & $9 \pm 2$ & $18 \pm 3$ & & $<1$ & $<1$ \\
\hline Bromes (Bromus spp.) & $1 \pm 2$ & $12 \pm 7$ & $13 \pm 11$ & $<1$ & $8 \pm 7$ & $14 \pm 6$ & & $<1$ & $<1$ \\
\hline Indian ricegrass (Oryzopsis hymenoides) & $4 \pm 6$ & $9 \pm 2$ & $8 \pm 5$ & $2 \pm 1$ & $3 \pm 3$ & $8 \pm 7$ & $<1$ & $<1$ & $<1$ \\
\hline Bluegrass (Poa sp.) & $1 \pm 1$ & $4 \pm 7$ & $13 \pm 18$ & $5 \pm 6$ & $<1$ & $11 \pm 8$ & & & $<1$ \\
\hline Fescue (Festuca spp.) & $3 \pm 2$ & $<1$ & $<1$ & $3 \pm 2$ & $<1$ & $<1$ & $<1$ & $<1$ & $<1$ \\
\hline \multicolumn{10}{|l|}{ Forbs and shrubs } \\
\hline Utah serviceberry (Amelanchier utahensis) & $8 \pm 11$ & $<1$ & $<1$ & $<1$ & $<1$ & $<1$ & $74 \pm 9$ & $68 \pm 15$ & $13 \pm 10$ \\
\hline Pinyon pine (Pinus edulis) & & & $<1$ & & $<1$ & $<1$ & $3 \pm 4$ & $11 \pm 10$ & $40 \pm 14$ \\
\hline Junipers (Juniperus spp.) & & & $<1$ & & & $<1$ & $2 \pm 2$ & $3 \pm 4$ & $38 \pm 16$ \\
\hline Bladderpod (Lesquerella sp.) & $<1$ & $<1$ & $<1$ & $<1$ & $<1$ & $<1$ & $3 \pm 2$ & $3 \pm 2$ & $3 \pm 3$ \\
\hline Barberry (Berberis sp.) & & & & & $<1$ & $<1$ & $4 \pm 5$ & $3 \pm 1$ & $<1$ \\
\hline Big sagebrush (Artemisia tridentata) & $<1$ & & & & & & $<1$ & $3 \pm 4$ & $3 \pm 4$ \\
\hline $\begin{array}{l}\text { True mountainmahogany (Cercocarpus } \\
\text { montanus) }\end{array}$ & $<1$ & & & & $<1$ & & $3 \pm 2$ & $2 \pm 1$ & $<1$ \\
\hline Snowberry (Symphoricarpos sp.) & & & & $<1$ & & $<1$ & $3 \pm 2$ & $<1$ & $<1$ \\
\hline Bluebells (Mertensia spp.) & $<1$ & & & $<1$ & $<1$ & & $3 \pm 1$ & $<1$ & $<1$ \\
\hline Rabbitbrushes (Chrysothamnus spp.) & $<1$ & $<1$ & $<1$ & $<1$ & $<1$ & $<1$ & $<1$ & $2 \pm 2$ & $1 \pm 1$ \\
\hline Gambel oak (Quercus gambeli) & $<1$ & & & & & & $2 \pm 2$ & $<1$ & $<1$ \\
\hline Common winterfat (Eurotia lanata) & $4 \pm 2$ & $2 \pm 1$ & $7 \pm 4$ & $5 \pm 1$ & $3 \pm 2$ & & $<1$ & $<1$ & $<1$ \\
\hline
\end{tabular}

Table 2. Mean similarity indexes $(\%)$ and rank-order correlation coefficients $\left(r_{\mathbf{s}}\right)$ comparing plant components of horse, cattle, and mule deer diets within three vegetation zones, Piceance Basin, Colo.

\begin{tabular}{|c|c|c|c|c|c|c|}
\hline \multirow[b]{3}{*}{ Vegetation zone } & \multicolumn{6}{|c|}{ Herbivores compared } \\
\hline & \multicolumn{2}{|c|}{$\begin{array}{l}\text { Horse vs } \\
\text { cattle }\end{array}$} & \multicolumn{2}{|c|}{$\begin{array}{l}\text { Horse vs } \\
\text { mule deer }\end{array}$} & \multicolumn{2}{|c|}{$\begin{array}{l}\text { Cattle vs } \\
\text { mule deer }\end{array}$} \\
\hline & $\%$ & $r_{\mathrm{s}}$ & $\%$ & $r_{\mathrm{s}}$ & $\%$ & $r_{\mathrm{s}}$ \\
\hline Mountain shrub & 71 & $0.83^{1}$ & 11 & -0.14 & 4 & 0.15 \\
\hline Ecotone & 75 & $0.86^{1}$ & 4 & -0.26 & 4 & -0.09 \\
\hline Pinyon-juniper & 59 & $0.79^{1}$ & 2 & -0.02 & 2 & -0.02 \\
\hline
\end{tabular}

'Correlation coefficients significant at the $2 \%$ level of probability.

Table 3. Mean similarity indexes (\%) and rank-order correlation coefficients $\left(r_{\mathbf{s}}\right)$ comparing plant components of horse, cattle, and mule deer diets between three vegetation zones, Piceance Basin, Colo.

\begin{tabular}{|c|c|c|c|c|c|c|}
\hline \multirow[b]{3}{*}{ Animal } & \multicolumn{6}{|c|}{ Vegetation zones compared $^{2}$} \\
\hline & \multicolumn{2}{|c|}{$\begin{array}{l}\text { Mountain shrub } \\
\text { vs ecotone }\end{array}$} & \multicolumn{2}{|c|}{$\begin{array}{c}\text { Mountain shrub } \\
\text { vs pinyon-juniper }\end{array}$} & \multicolumn{2}{|c|}{$\begin{array}{l}\text { Pinyon-junipe } \\
\text { vs ecotone }\end{array}$} \\
\hline & $\%$ & $r_{\mathrm{s}}$ & $\%$ & $r_{\mathrm{s}}$ & $\%$ & $r_{\mathrm{s}}$ \\
\hline Horse & 53 & 0.86 & 37 & 0.67 & 53 & 0.80 \\
\hline Cattle & 48 & 0.84 & 44 & 0.78 & 53 & 0.75 \\
\hline Mule deer & 74 & 0.66 & 21 & 0.59 & 33 & 0.84 \\
\hline
\end{tabular}

'Five pairs of diets were used in each comparison.

"All correlation coefficients are significant at the $1 \%$ level of probability.

The principal foods $(>5 \%)$ of both wild horses and cattle were sedges, needleandthread, wheatgrasses, prairie Junegrass, bromes, Indian ricegrass, bluegrasses, and common winterfat (Table 1). Utah serviceberry, one of the most abundant plants in the upper zones, was a principal food of wild horses only in the mountain shrub zone. Utah serviceberry, pinyon pine, and
Table 4. Mean trophic diversity indexes for horse, cattle, and mule deer diets in three vegetation zones, Piceance Basin, Colo.

\begin{tabular}{llll}
\hline & \multicolumn{3}{c}{ Herbivore } \\
\cline { 2 - 4 } Vegetation type & Horse & Cattle & Deer \\
\hline Mixed mountain & & & \\
shrub & $1.66 \mathrm{abd}^{1}$ & $1.41 \mathrm{acd}$ & $2.24 \mathrm{c}$ \\
Ecotone & $1.83 \mathrm{ab}$ & $1.75 \mathrm{ab}$ & $1.23 \mathrm{~cd}$ \\
Pinyon-juniper & $1.88 \mathrm{ab}$ & $2.12 \mathrm{~b}$ & $1.41 \mathrm{~cd}$ \\
\hline 'Means followed by the same letter are not significantly different $(\alpha=.05)$ by Newman- \\
Keuls multiple range test.
\end{tabular}

juniper were the only forages which averaged at least $5 \%$ of the mule deer diet in any vegetation zone (Table 1).

\section{Discussion}

The rank-order correlation coefficients for foods eaten by wild horses and cattle were significantly correlated within each vegetation zone (Table 2). The correlation coefficients between deer diets and wild horses or cattle were not significant and the coefficients were negative in each zone except in the mountain shrub zone for diets of wild horses and deer. High dietary overlaps and significant positive correlation coefficients between wild horses and cattle suggest competitive potential food relationship could develop if the stocking rates of horses and cattle are not balanced with the production of sedges and grasses in the Piceance Basin.

The negative correlation for deer diets and those of wild horses or cattle suggests complemetary rather than competitive potential food relationships. The wild horses and deer both consumed high percentages of Utah serviceberry in the mountain shrub zone, and although the correlation coefficient was positive but not significant, we do not believe they could be in competition for food at the present time because of the apparent superabundance of nonbrowsed serviceberry plants in this zone. 
We feel that the combined use by wild horses and cattle was currently not excessive. The condition of the deer browse plants in this area suggests that deer are understocked, especially in the mountain shrub and ecotone zones. Excessive grazing by either wild horses or cattle may cause plant successions which favor increased production for deer forage.

When sampling for herbivore dung we observed that the relative amounts varied for species of herbivores between the different zones. Assuming that the amount of dung per species of herbivore reflected amount of herbage eaten, we feel that wild horses were consuming more forage than cattle, and cattle more than deer in the upper two vegetation zones. In the pinyon-juniper zone, we believe mule deer may consume more forage than either wild horses or cattle, and cattle consumed more forage than wild horses. We believe cattle and wild horse grazing is not responsible for the recent decline in mule deer populations in the Piceance Basin.

There is need for additional research on the food relationships of large and small herbivores in the Piceance Basin. In future studies it would be desirable to simultaneously quantify food habits, food distribution, herbage production and herbivore populations by seasons.

\section{Literature Cited}

Baker, B. D. 1970. Survey, inventory, and analysis of deer and elk winter range; Appendix B. Big game winter range anaysis. Game Unit 22Piceance. Vol. Progress Rep., Fed. Aid Proj. W-101-R-12, Colorado Game, Fish and Parks Div., Denver. July (Part 1):31-58.

Beetle, A. A. 1970. Recommended plant names. Univ. Wyoming Agr. Exp. Sta. Res. J. 31. Laramie, Wyo. 124 p.

Committee of the Soil Conservation Workshops. 1957. Livestock and deerr ratios for Texas rangelands. Texas Agr. Exp. Sta. Misc. Pub. 221. 9 p.

Constan, K. J. 1973. Winter foods and range use of three species of ungulates. J. Wildl. Manage. 36:1068-1076.

Conk, C. W. 1954. Common use of summer range by sheep and cattle. J. Range Manage. 7:10-13.

Cook, C. W. 1974. Surface rehabilitation of land disturbances resulting from oil shale development. Environmental Resources Center Information Series 11, Colo. State Univ., Fort Collins. $56 \mathrm{p}$.

Cook, C. W. 1975. Wild horses and burros: a new management problem. Rangeman's J. 2:19-21.

Conk, C. W., R. M. Hyde, and P. L. Sims. 1974. Guidelines for revegetation and stabilization of surface mined areas in the western states. Range Sci. Dep. Sci. Ser. 16, Colo. State Univ., Fort Collins. 70 p.

Davis, R. B. 1952. The use of rumen contents data in a study of deer-cattle competition and "animal equivalence." Trans. N. Amer. Wildl. Conf. 17:448-458.

Dearden, B. L., R. E. Pegau, and R. M. Hansen. 1975. Precision of microhistological estimates of ruminant food habits. J. Wildl. Manage. 39: 402-407.

Dixon, W. J., Ed. 1972. University of California publications in automatic computation no. 3, BMD biomedical computer programs, $x$-series supplement. Univ. Calif. Press, Berkeley, Los Angeles, London.

Flinders, J. T., and R. M. Hansen. 1972. Diets and habitats of jackrabbits in northeastern Colorado. Range Sci. Dep. Sci. Ser. 12, Colo. State Univ., Fort Collins. 29 p.

Hansen, R. M., D. G. Peden, and R. W. Rice. 1973. Discerned fragments in feccs indicates diet overlap. J. Range Manage. 26:103-105.

Hansen, R. M., and L. D. Reid. 1975. Diet overlap of deer, elk, and cattle in southern Colorado. J. Range Manage. 28:43-47.

Hurtubia, J. 1973. Trophic diversity measurement in sympatric predatory species. Ecology 54:885-890.

Julander, O. 1955. Deer and cattle range relations in Utah. Forest Sci. 1:130-139.

Kufeld, R. C., O. C. Wallmo, and C. Feddema. 1973. Foods of the rocky mountain mule deer. U.S. Forest Serv, , Rocky Mountain Forest and Range Exp. Sta. Res. Pap. RM-111. Fort Collins, Colo. 31 p.

Mackie, R. J. 1970. Range ecology and relations of mule deer, elk, and cattle in the Missouri River breaks, Montana. Wildl. Monogr. No. 20. 79 p.

McKean, W. T., and R. W. Bartmann. 1971. Deer-livestock relations of a pinyon-juniper range in northwestern Colorado. Colo. Game, Fish and Parks Rep. W-101-R. Fort Collins, Colo. 132 p.

Miller, R. G. 1966. Simultaneous statistical inference. McGraw-Hill Book Co., New York. 272 p.

Morrison, D. F. 1967. Multivariate statistical methods. McGraw-Hill Book Co., New York. $338 \mathrm{p}$.

Oosting, H. J. 1956. The study of plant communities. W. H. Freeman and Co., San Francisco. 440 p.

Schwan, H. E. 1945. Big game and livestock on the western range. Trans. N. Amer. Wildl. Conf. 10:219-224.

Shannon, C. E. 1948. A mathematical theory of communication. Bell Systems Tech. J. 27:378-423, 623-656.

Siegel, S. 1956. Nonparametric statistics for the behavioral sciences. McGrawHill Book Co., New York. 312 p.

Snedecor, G. W., and W. G. Cochran. 1973. Statistical methods. lowa State Univ. Press, Ames. 593 p.

Sparks, D. R., and J. C. Malechek. 1968. Estimating percentage dry weight in diets using a microscope technique. J. Range Manage. 21:264-265.

Todd, J. W., and R. M. Hansen. 1973. Plant fragments in the feces of bighorns as indicators of food habits. J. Wildl. Manage. 37:363-366. 